\title{
The Case for a Single Currency
}

\author{
Barbara L. Neuby ${ }^{1}$, Sandra M. Barrett ${ }^{2}$ \\ ${ }^{1}$ Kennesaw State University, Kennesaw, Georgia, USA \\ ${ }^{2}$ Sandra Barrett, MBA, MPA, Program Advocate-Victim Services, State of Georgia, USA \\ Email: bneuby@kennesaw.edu; sbarrett670@gmail.com
}

\begin{abstract}
Amidst the continued economic woes in the EU, lagging growth in China, the relative strengths and weaknesses of the dollar and other major currencies, and various and sundry articles about banker fraud, derivative-induced collapses, and general economic malaise, there lies an undercurrent of debate about a potential common monetary destiny: a single global currency. This paper evaluates eight currency candidates across the three roles of money and creates a typology of 70 nations using aggregate freedom scores from Freedom House and data from Bank for International Settlements (BIS) and the International Monetary Fund (IMF) to estimate banking system soundness. While some monetary units appear better suited for the monopoly role, none satisfies political criteria. Thirty-five nations scored well on total freedom and banking system stability and may serve as initial adopters if a currency candidate survives the political environment. Implementation concerns remain.
\end{abstract}

Keywords: Global currency; currency; monetary reform; world currency

\section{The International Monetary System (IMS)}

The international monetary system is composed of exchange rate arrangements, capital flows and institutions, rules, and conventions governing the system's operations. Domestic policy generally falls into conformance [1]. Many argue that the international monetary system (IMS) is in desperate need of reform and that something must be done very soon to avoid catastrophe [1, 2, 3, 4, 5]. Alessandrini and Fratianni argue that the global instability derives from a deteriorating US dollar [6] and Subacchi called our system of volatile fiscal normalcy, "stable disequilibrium" [4, 668] presumably because it suffers from monstrous complexity, overextensions, burdensome debt and deficits, development here but poverty there, and central banks that have run out of ammunition to salve the world's economic wounds. Exchange rate and balance of payment imbalances, deflation in commodity demand, sudden currency devaluations, latent and patent wars, civil and religious conflicts, terrorism and fiscal imbalance, structural unemployment, and anti-austerity rallies [7] have prompted many to argue the time is right to move toward a single currency. But why would a single unit solve these problems? Exchange rate and balance of payments problems serve as a primary impetus for a single currency while others feel, for reasons of equity and cooperation, it is time to move away from a one currency reserve and create a new unit based on a basket of several existing, strong currencies.

\section{Methodology}

The shift to a single currency would represent a policy change of massive global proportions. Every nation, its businesses, every central bank, world bodies, retailers, households, and debt and pension fund holders would undergo huge recalculations in their budgets or portfolios. In the world of geopolitics, nothing is certain and, in modern times, since the modern world has never seen a global currency, there is no direct data by which to measure the success of one currency option over another. We began with an a priori theory that a single currency is "possible," and we conducted a thought experiment with two units of analysis: potential currency options and nations that might adopt a sole unit. A purposeful sampling of currency options comes from a review of history and current documentation. The changeover to the euro provides details that help us understand the adoption process.

What are the potential units that might serve in the single currency role and how would each satisfy 
that role? Is the world moving in this direction? What conditions would support a single global? We compare each possible currency unit to the accepted three-part definition of money: a store of value, a means of exchange, and a unit of account [8]. We couple this definition with a policy analysis criterion, that of political acceptability. Without some degree of political acceptability, absent horrific crisis, nations are likely to be reluctant to relinquish their sovereign or regional unit. Content analysis of scholarly literature and institutional documents was performed using the terms "single currency," "world currency," "one currency," or "global currency," and "monetary reform." Over a thousand articles were sorted by relevance and date. Substantive positive comment regarding movement away from either the dollar as a reserve unit or toward a single global unit was recorded as favoring a global currency. Content analysis was refined to locate articles that discussed a currency in the three roles of money.

Review of documentation from the Bank for International Settlements (BIS) and the International Monetary Fund (IMF) and other institutions as well as scholarly literature supplied criteria for governmental adoption of a new currency. Adoption of the euro supports the usefulness of these criteria. Nations that initially adopted the new unit were multi-party, democratic systems: free nations with functioning political institutions, a free press, and civil rights. We used Freedom House's, Freedom in the World, aggregate scores as a measure of these criteria [9]. In the euro's case, a new financial institution was created, that of the European Central Bank (ECB). The ECB was instrumental in working with existing sovereign banks and private institutions to adapt their public sector to the new currency.

Nations ready to adopt a new single currency must also have functioning financial systems that include a central bank and regulatory authorities that offer capacity and integrity. Stability in the central bank and soundness in the banking sector are essential criteria for monetary reform. Basel II reforms required banks to have financial security measures and the deadline for implementation of Basel II was 2014. The BIS scored nations on the level of adoption of Basel II and we used this score as a measure of bank stability and integrity. The IMF provided data on bank capital to assets ratios for most countries and this score was used as a measure of banking system soundness and capacity. A pool of countries was located for which consistent data was available. Seventy countries' data was recorded for these 3 variables and scores were standardized (z-scores) and added to produce a country favorability score for single currency adoption.

\section{$3 \quad$ Literature Review}

The one currency idea is not new: it has existed in one form or another since the 1700s, revived by Keynes and White in the 1930s, and rose from the grave in 1969 when MIT economics professor Kindleberger said the best monetary system was, "world money with a world monetary authority [10 pp105]." Coats, Cooper, and Hayek [11. 12, 13] suggested government monopoly of money was the cause of crises. Rogoff agreed that a single currency would ameliorate the exchange rate problem but felt currency competition was good [14]. However, Rogoff wrote prior to the financial crisis of 2008-2009. Robert Mundell, known as the father of the Euro, brought back those pesky exchange rates as a main reason for one currency [15] and Steil [16], Carney [1], Bird [17], Eichengreen [18], and dozens more agreed that a single currency would go a long way toward making these needed changes.

Exchange rates serve as the backbone of international trade and finance. Global businesses and sovereign powers are accustomed to operating within the confines of the exchange rate world expending time and money in an effort to hedge their bets and making bankers rich in the process. Rahn [19] and Hayek [13] argue that a multi-currency world has produced a world full of investment and trade and policy problems, latent wars, and deflation and nearly every global body and dozens of scholars agree [2, $3,20,21,22]$.

Adopting a single currency is said to eliminate these problems that cause great concern among policy makers and monetary authorities. Reams of literature attempt to explain what drives exchange rates and, in turn, what exchange rate shifts may cause but it is clear that the exchange rate problem is complicate by many factors. Sarno and Schmeling [23] argued that macro-fundamentals like monetary and fiscal policy impact exchange rates while Beckmann and Czudaj said the difficulty in predicting rates brings monetary and fiscal policy uncertainty [24]. Sarno and Schmeling found that those exchange rates drove interest rates, inflation, money balances, and GDP. Zhang and MacDonald [25] claimed a 
negative long-term relationship between exchange rates and trade imbalances exists while Duarte and Schnabl maintained that exchange rates do not cause trade imbalances but, rather, imbalances are caused by poor monetary and fiscal policy at least in emerging markets [26].

The story of the Swiss National Bank's (SNB) attempt to peg the franc to the euro is illustrative of the difficulty in managing, or, "manipulating," the exchange rate. By 2014, the franc had strengthened against the euro and the SNB purchased other currencies to weaken it. Finally, in early 2015, the SNB de-pegged the franc to the euro and within one day the franc rose twenty percent against the euro [27]. Exchange rates are used as a principle currency value and then serve as a basis for policy adjustment, it would seem that exchange rates could impact GDP, fiscal policy, trade imbalances, and even urge firms to enter or leave the market [28].

Cheaper exchange rates serve as a subsidy to exporters and a duty to importers [27] and countries with a strict or less flexible exchange rate regime are less likely to sell bonds [29]. Lower inflation often increases currency values but the issue is complicated by the fact that central banks exert influence over both inflation and exchange rates through monetary policy. Debt financing for public projects, while stimulating economies, may also increase debt and deficits, resulting in a weaker currency. Easy money policy generally produces inflation, lenders worry about ability to pay off debt, lending may dry up and the currency weakens. Credit ratings may drop and down goes the exchange rate. Finally, economic performance and political stability attract foreign capital and are generally associated with stronger currencies and higher exchange rates. Table 1 illustrates correlation coefficients of currency pairs in 2017.

Table 1. Exchange rate correlations between selected nations

\begin{tabular}{l|l|l|l|l|l|l}
\hline EUR/USD & AUD/USD & USD/JPY & GBP/USG & NZD/USD & USD/CHF & USD/CAD \\
\hline $\mathbf{1}$ month & .74 & .44 & .95 & .84 & -1.00 & -.31 \\
\hline $\mathbf{3}$ months & .77 & -.42 & .90 & .69 & -.96 & -.18 \\
\hline $\mathbf{6}$ months & .50 & -.34 & .66 & .66 & -.90 & -.22 \\
\hline $\mathbf{1}$ year & .93 & -.55 & .89 & .89 & -.97 & -.90 \\
\hline
\end{tabular}

Table 1 shows that those in global trade, finance, or those who engage in foreign currency trading would need to constantly stay on top of exchange rate movements as rates between currency pairs swing back and forth from positive to negative over the course of days or months evidencing problems discussed earlier. Although correlations between exchange rates can easily be determined, they are difficult to predict. Burckhardt showed that macroeconomic factors correlate only weakly with exchange rates and commodity prices in a period of 156 weeks from 2005 through 2007 [30]. Drozdz, Gorski and Kwapien indicated that exchange rate correlations depend upon which currency is used as a reference point in their study of 60 currencies from 1998 to 2005 [31], and a U.S. Federal Reserve working paper demonstrated that as interest rate differentials in currency pairs increases, the exchange rate correlation decreases [32]. Knowing how currencies move against others provides essential international trade and finance information but, if they are difficult to predict and cause many types of instability and balance of payments problems, then perhaps the elites and institutions are correct in veering away from the current multi-currency system.

Other reasons for moving toward a single currency include equity and cooperation. Xiaochuan Zhou, former Director of the Peoples Bank of China, believed that the dollar needs to be replaced with a suitable supranational currency, arguing that no one currency should have reserve status and that a larger basket of currencies would, "achieve the objective of safeguarding global economic and financial stability [5]." Researchers at the IMF agree [33, 34]. Russia, Brazil, India, and China (the BRIC countries) have also openly called for reform to the reserve status system and have been diversifying their assets away from the dollar. In 2009 the United Nations (UN) claimed that if we moved away from the dollar and toward a truly global monetary system many of the world's problems would self-adjust [35].

Various notables have reiterated the call. Paul Volcker, former U.S. Federal Reserve Chairman stated, "A global economy requires a global currency [36]." Tim Geithner, former U.S. Treasury Secretary, said in 2009 in post-crisis days, "we'd be quite open to that [37]." Former French President Sarkozy, former British Prime Minister Tony Blair, Russian President Medvedev, and even Pope Francis have publicly 
supported a single currency [38] as have market watch companies who say it is time to move away from multi-currency period into a one-world system [39].

\section{International Currency Use}

If currency is money and money fulfills three roles, then any potential candidate for a single currency must meet these demands. Additionally, global financial institutions and nations must accede to use of such a currency. In Table 2, five fiat currencies are compared for their respective usage over five categories for 2015: the foreign exchange market (FOREX), foreign exchange reserves, international trade, bank deposits, and debt securities. A monetary unit must be recognized as one of value, it must be freely exchanged, and used as a unit of account. Political acceptability will be treated separately.

The dollar remains predominant as the world's reserve unit because it represents 87 percent of the foreign exchange market, 63 percent of reserves, half of international trade and slightly more than half of bank deposits around the world as of 2015. Only in the category of debt securities does the euro bond rival the dollar's preeminence. The yuan/RMB is coming on strong in international markets. Euro bonds, since their inception, have challenged U.S. bonds for hegemony and Japan's securities remain weak in the market. The pound's future remains uncertain until the Brexit decision is finalized. The yen is influential in the foreign exchange market, and the elevation of the RMB brings a relatively new player to the game.

Table 2. Select indicators for key currencies- as percentage of world total.

\begin{tabular}{l|l|l|l|l|l}
\hline Use & Dollar & Euro & Pound Sterling & Yen & Yuan (RMB) \\
\hline Foreign Exchange Market & $87.0^{*}$ & $33.4^{*}$ & 11.8 & 23.0 & 2.2 \\
\hline Foreign Exchange Reserves & 62.9 & 22.2 & 3.8 & 4.0 & 1.0 \\
\hline International Trade & 50.3 & 37.3 & -- & -- & 1.4 \\
\hline Bank Deposits & 57.3 & 22.7 & 5.2 & 2.9 & 1.9 \\
\hline Debt Securities & 40.4 & 40.9 & 9.6 & 2.0 & .06 \\
\hline
\end{tabular}

${ }^{*}$ Does not sum to $100 \%$ because each transaction includes two currencies.

Table 3. Currency candidates evaluated on three-part definition of money

\begin{tabular}{l|l|l|l|l}
\hline Currency & Means of Exchange & Store of Value & Unit of Account & Total Score \\
\hline Dollar & 1 & 1 & 1 & 3 \\
\hline Euro & 1 & 1 & 1 & 3 \\
\hline Yen & 1 & 0 & 1 & 2 \\
\hline Yuan/RMB & 1 & 0 & 1 & 2 \\
\hline Pound & 1 & 0 & 1 & 2 \\
\hline Bitcoin & 0 & 0 & 1 & 1 \\
\hline Gold/Silver & 0 & 1 & 0 & 1 \\
\hline SDRs & 0 & 0 & 1 & 1 \\
\hline
\end{tabular}

In Table 3, five fiat currencies, bitcoin, gold/silver, and Special Drawing Rights (SDRs) are evaluated against the three-part definition of money as described by various institutional white papers and scholars. A " 1 " is placed in each cell of the currency role fulfilled.

Despite the dollar's dominance, it remains challenged from the "Triffin Dilemma." The dollar must be abundant to promote liquidity yet safe enough to promote a stable reserve asset. With a U.S. debt of $\$ 20$ trillion, a debt-to-GDP ratio of over 100 percent, fiscal issues, and central bank loss of control, the dollar's statistics belie its structural foundation [2, 3, 18]. According to many financial elite and a handful of world leaders the world is over the dollar yet it remains the Big Man on Campus. China and the UN say it is unstable [5,35], that its continued use threatens the very global stability for which others credit it for providing $[20,40,41]$. Others claim that one reserve currency is unfair to other nations especially when exchange rates are considered [1,5]. Robert Mundell [15] said the dollar was in 
crisis two decades ago. Asian finance ministers have called for another system to replace the dollar as hegemon and they reiterate that call today through the new, Chinese-led Asian Infrastructure Bank to which many U.S. allies have joined [35, 42]. James Rickards, author of Currency Wars and The Death of Money says that for many reasons the dollar is unsustainable [43, 44], and Eichengreen [18] joins nearly every world financial institution (IMF, UN, World Bank, BIS) in their concern that global investors are worried about the level of debt and deficits the U.S. holds. The dollar scores well as an effective unit of account and means of exchange because of its widespread use. The percentage of reserves in dollars shows that most consider the currency a store of value even if it is fiat unit. The dollar shares a level of political acceptability with the other fiat units and at a 50 percent share of trade certainly qualifies as a means of exchange at the present time.

Many see the euro as just as unstable as the dollar if not more so [5, 35, 45] and most admit the euro is not ready to take the dollar's place [4, 6,41]. It could threaten the dollar's reserve status if one considers that aggregated EU GDP is equal to that of the United States, or approximately $\$ 16$ trillion as of 2015 [21]. The market for euro bonds, currency trades, and the euro's share of international trade is growing. It is now 22 percent of global foreign reserves $[2,46]$.

The euro serves all three roles of money, is broadly accepted within and without to Eurozone, and could grow into an effective single unit. In addition, processes are underway to incorporate broader member input into currency management. The EU and European Central Bank possess significant financial skill and will elevate the euro but there are no serious proposals from any EU finance minister, ECB or UN leader to do so.

Japan's yen is the third most actively traded currency in the forex market at 23 percent but that is where the bright spots end, for the yen accounts for merely 5 percent of global GDP, and less than 5 percent of bank deposits and debt securities [2]. Yen stability has been a concern because Japan's debtto-GDP ratio is over 200 percent, due largely to quantitative easing [47]. But the Japanese markets are liquid, fluid, and mature, and the yen is freely traded in currency and in sovereign bonds but accounts for less than 5 percent of reserves. The important point here is that the world is not heavily and eagerly invested in yen-denominated securities and there is no evidence to the contrary that this pattern will change. It serves as money in all three roles for Japan but the argument can be made that it would be the weakest of the five fiat currencies for the aforementioned reasons. No leader or institution has a proposal on their agenda or radar to elevate the yen to a reserve currency status and there is no dialogue about same in the literature.

While China becomes the newest member of the SDR basket, not even China's central bank has suggested that the renminbi (RMB) fulfills the role of a single currency nor has that idea been debated in financial circles. China is the world's largest creditor nation and has massive debt but also a massive trade surplus, mostly in dollars. While their GDP has grown tremendously since China opened to the world, ${ }^{1}$ the RMB is a newcomer to the forex market and is barely accountable in measurements of reserves, debts securities, and bank deposits [21]. It serves the Chinese and Asian markets but is not broadly convertible or, as yet, highly desired according to the three part definition of money [3, 44]. The Chinese market is highly regulated, includes capital controls but few nations hold RMB in reserves [33]. The RMB is not easily convertible and, like the yen, is relatively inexpensive. Membership in the SDR basket is an element of political acceptability. The RMB serves all the roles of money in its sphere, and that sphere is growing but for now, there is no discussion of making it a legal global unit $[4,5,16]$.

In the 1800s, the British pound was the world's de facto reserve currency because it was supported by the throne, the colonial holdings, and the influence and power that came along with them. By 1900 the dollar, supported by its manufacturing base and ascendant political and military power, overtook the pound, and by 1945, Britain was the world's largest debtor nation. Still with immense wealth, the pound is not a candidate for a reserve currency. Accounting for only 11 percent of the forex market and less than 4 percent of reserves, it does not appear that the pound (in whatever reinvented, post-Brexit format) can serve as a store of value because it is not a desired global reserve unit (See Table 2). Although it is freely traded (means of exchange), has broad and deep markets, many would suffer should the currency be a sudden standard and there is no evidence that the crown is interested in elevating the pound.

\footnotetext{
${ }^{1}$ roughly 11 trillion dollars in 2015
} 
Bitcoin is fiat currency much the same as the aforementioned units with the exception that this unit is mined by a computer algorithm. Bitcoin is lauded and reviled in the literature as a successor to the dollar as a world currency because of its electronic cache [48. 49, 50]. Disconnected from any central bank or government monopoly, bitcoin is an anti-currency currency that exists outside the control of sovereign governments, but at a limit of 21 million bitcoins, it holds a tiny share of the global market [51]. Bitcoin's architecture is private and it is a freely exchanged unit of account whose value lay with those who use it [52]. Traded by thousands of merchants around the world, bitcoin's use remains a minute fraction of all exchanges [49]. Its current volatility would worsen the exchange rate problem. Elevating bitcoin is not on the radar of any institution, global or national, although they are beginning to regulate transactions out of concern over lost taxation [48]. While the e-currency approach offers speed and accounting as advantages to currency masters, bitcoin's volatility and logistical limitations mean it is not a serious challenge to the monopoly of the fiat currency.

The story of gold and silver is as old as history itself and that history can educate policy makers. Resource scarcity limits monetary expansion. They are finite resources, expensive to mine and refine, and require secure storage. Current estimates of gold resources are somewhere 120,000 and 140,000 tons above ground and about 48,000 tons as yet unmined [53]. Silver estimates are approximately 530,000 metric tons [54]. Estimates of national holdings of gold and silver are indicative of two things: one, that gold has value or nations would not be secretly holding it and, two, if gold and silver were not important to the currency debate, every nation would be openly discussing their holdings. Every country has gold in storage. The United States claims it holds 8,100 tons while China states that they have 3,500 tons [54]. Many in global financial circles believe China has at least twice that amount [55], and Fort Knox in the United States has not been audited in 42 years, since 1974. Thus, if one conservatively assumes that there are 120,000 tons plus another 48,000 tons as yet unmined, then there are 168,000 tons of gold. At a $\$ 1200$ per ounce conversion rate, gold is worth 7.1 trillion dollars, and silver, at $\$ 17.50$ an ounce in 2016, has a total value of 3.27 trillion dollars. The total would not be sufficient to adopt a 1 to 1 reconversion of gold to dollars and another formula would have to be created in order to use gold as money. Neither is a unit of account today as it once was but it is clearly a store of value or nations would not be hoarding it.

The SDR is an electronic unit of account created by the IMF in 1969 for the purpose of correcting temporary shortfalls and imbalances. It is a basket currency of the 5 fiat currencies, and, as of 2016, includes the RMB. IMF Articles of Incorporation indicate that the SDR was designed to be a global reserve currency someday [20]. Since then, discussions have focused debate on how to accomplish that goal. IMF white papers have analyzed the issue and made recommendations. In one paper, the SDR is rebranded as a parallel currency if a central bank and government coordination, a liquid market with hedging opportunity, and an operating board could be created in an incremental approach [34]. Subsequently, in 2011, a 40-point plan emerges, "Enhancing International Monetary Stability" that describes how SDRs could be a means of exchange and a store of value [33]. SDRs are not really exchanged in trade and have no intrinsic value in and of themselves. Used as a means of exchange SDRs would reduce volatility, accommodate emerging market countries, and create a new class of reserve assets with hedging opportunity (p1).

The IMF also asserts that SDRs cannot be used for market intervention and liquidity and that "tight political and legal constraints" stand in the way of its preeminence. Elevating its role further will require a "substantial investment of political will and consensus building" that it does not see occurring (p5) even though the United Nations and China support the IMF. Therefore, the IMF will have to go about implementation in other, more subtle, ways and the IMF clams it is prepared to work behind the scenes to make this big step happen (pp11).

\section{$5 \quad$ Findings}

The typology tallies the scores for our 70-nation sample. Freedom House ranked nations from 0 to 100 depending upon the openness and accountability of their institutions and press freedoms and civil rights. Each region of the world is represented. As shown by the changeover to the euro, banking capacity and stability are essential factors. The BIS scores nations on Basel II implementation of a range of capacity measures from 0 to 4 where " 0 " is no draft rule available and " 4 " is rules are published and 
implemented. The IMF records data on banking system stability and we used the ratio of capital to assets as shown in Table 4 below. Each set of variable scores were standardized (z-scores) and tallied to produce a final score. Final scores are plotted on a graph in Figure 1.

Table 4a. Favorable factors for currency adoption- 70 nations

\begin{tabular}{|c|c|c|c|c|c|c|c|c|}
\hline No & Nation/KEY & $\begin{array}{l}\text { Freedom } \\
\text { Score }\end{array}$ & $\begin{array}{l}\text { Freedom } \\
\text { Score (Z- } \\
\text { Score) }\end{array}$ & $\begin{array}{l}\text { Banking } \\
\text { Stability }^{1}\end{array}$ & $\begin{array}{l}\text { Standard } \\
\text { Score (Z- } \\
\text { Score) }\end{array}$ & $\begin{array}{l}\text { Capital } \\
\text { to Asset } \\
\text { Ratio }\end{array}$ & $\begin{array}{l}\text { Ratio } \\
\text { Standard } \\
\text { Score } \\
\text { (Z-score) } \\
\end{array}$ & $\begin{array}{l}\text { Total } \\
\text { Score }\end{array}$ \\
\hline 1 & Afghanistan AFG & 24 & -1.86 & 1 & -2.15 & 20.94 & 1.05 & -2.96 \\
\hline 2 & Argentina/ARG & 79 & .26 & 2 & -1.26 & 16.07 & -.07 & -1.07 \\
\hline 3 & Australia/AUS & 98 & 1.00 & 4 & .53 & 14.02 & -.55 & -4.03 \\
\hline 4 & Austria/AST & 95 & .88 & 4 & .53 & 16.83 & .10 & 1.51 \\
\hline 5 & Bangladesh/BAN & 49 & -.89 & 4 & .53 & 10.59 & -1.35 & -1.71 \\
\hline 6 & Belarus/BEL & 17 & -2.13 & 4 & .53 & 18.70 & .53 & -0.20 \\
\hline 7 & Belgium/BLG & 96 & .92 & 4 & .53 & 18.35 & .45 & 1.90 \\
\hline 8 & Bhutan/BHU & 56 & -.62 & 1 & -2.15 & 17.94 & .35 & -2.42 \\
\hline 9 & Bolivia/BOL & 68 & -.15 & 4 & .53 & 13.67 & -.63 & -0.52 \\
\hline 10 & Bosnia-Herz/BOS & 57 & -.58 & 1 & -2.15 & 15.83 & -.13 & -2.86 \\
\hline 11 & Botswana/BOT & 73 & .03 & 1 & -2.15 & 18.79 & .55 & -1.57 \\
\hline 12 & Brazil/BRZ & 81 & .34 & 4 & .53 & 16.54 & .03 & 0.90 \\
\hline 13 & Canada/CAN & 99 & 1.04 & 4 & .53 & 14.20 & -.51 & 1.06 \\
\hline 14 & Chile/CHI & 95 & .88 & 2 & -1.26 & 12.62 & -.88 & -1.26 \\
\hline 15 & China/CHN & 16 & -2.17 & 4 & .53 & 13.41 & -.69 & -2.33 \\
\hline 16 & Colombia/COL & 63 & -.35 & - & - & 17.70 & .30 & -0.05 \\
\hline 17 & Congo/CON & 28 & -1.70 & 1 & -2.15 & 19.79 & .79 & -3.06 \\
\hline 18 & Costa Rica /CR & 90 & .69 & 2 & -1.26 & 16.54 & .03 & -0.54 \\
\hline 19 & El Salvador/ELS & 69 & -.12 & 1 & -2.15 & 17.31 & .21 & -2.06 \\
\hline 20 & Ecuador/ECU & 59 & -.50 & 2 & -1.26 & 18.89 & .58 & -1.18 \\
\hline 21 & Egypt/EGP & 27 & -1.74 & 4 & .53 & $6.20^{*}$ & -2.37 & -3.58 \\
\hline 22 & Finland/FIN & 100 & 1.07 & 4 & .53 & 22.78 & 1.48 & 3.08 \\
\hline 23 & France/FRA & 91 & .73 & 4 & .53 & 17.19 & .18 & 1.44 \\
\hline 24 & Gambia/GAM & 18 & -2.09 & 1 & -2.15 & 37.60 & 4.94 & 0.70 \\
\hline 25 & Georgia/GEO & 64 & -.31 & 4 & .53 & 17.50 & .25 & 0.47 \\
\hline 26 & Germany/GER & 95 & .88 & 4 & .53 & 18.15 & .40 & 1.81 \\
\hline 27 & Ghana/GHA & 83 & .42 & - & - & 16.18 & -.05 & 0.37 \\
\hline 28 & Greece/GRE & 83 & .42 & - & - & 18.01 & .37 & 0.79 \\
\hline 29 & Iceland/ICE & 100 & 1.07 & 4 & .53 & 23.30 & 1.60 & 3.20 \\
\hline 30 & India/IRE & 77 & .18 & 4 & .53 & 13.03 & -.78 & -0.07 \\
\hline 31 & Indonesia/IDN & 65 & -.27 & 4 & .53 & 21.17 & 1.11 & 1.37 \\
\hline 32 & Ireland/IRE & 96 & .92 & 4 & .53 & 13.35 & -.71 & 0.74 \\
\hline 33 & Israel/ISR & 80 & .30 & 4 & .53 & 14.25 & -.50 & 0.33 \\
\hline 34 & Italy/ITY & 89 & .65 & 4 & .53 & 14.97 & -.33 & 0.85 \\
\hline 35 & Japan/JAP & 96 & .92 & 4 & .53 & 15.94 & -.10 & 1.35 \\
\hline 36 & Kazakstan/KZK & 24 & -1.86 & 3 & -.36 & 16.49 & .02 & -2.20 \\
\hline 37 & Kenya/KEN & 51 & -.81 & 1 & -2.15 & 18.13 & .40 & -2.56 \\
\hline 38 & Latvia/LAT & 86 & .53 & 4 & .53 & 18.44 & .47 & 1.53 \\
\hline
\end{tabular}


Table 4 b. Favorable factors for currency adoption- 70 nations

\begin{tabular}{|c|c|c|c|c|c|c|c|c|}
\hline No. & Nation/KEY & $\begin{array}{l}\text { Freedom } \\
\text { Score }\end{array}$ & $\begin{array}{l}\text { Freedom } \\
\text { Score } \\
\text { (Z- } \\
\text { Score) }\end{array}$ & $\begin{array}{l}\text { Banking } \\
\text { Stability }\end{array}$ & $\begin{array}{l}\text { Standard } \\
\text { Score (Z- } \\
\text { Score) }\end{array}$ & $\begin{array}{l}\text { Capital } \\
\text { to } \\
\text { Asset } \\
\text { Ratio }\end{array}$ & $\begin{array}{l}\text { Ratio } \\
\text { Standard } \\
\text { Score (Z- } \\
\text { Score) }\end{array}$ & $\begin{array}{l}\text { Total } \\
\text { Score }\end{array}$ \\
\hline 39 & Lebanon/LEB & 43 & -1.12 & 4 & .53 & $7.90 *$ & -1.98 & -2.57 \\
\hline 40 & Lithuania/LIT & 91 & .73 & 4 & .53 & 19.32 & .68 & 1.94 \\
\hline 41 & Malaysia/MLY & 45 & -1.05 & 3 & -.36 & 16.77 & .08 & -1.33 \\
\hline 42 & Malta/MLT & 96 & .92 & 4 & .53 & 15.75 & -.15 & 1.30 \\
\hline 43 & Mauritius/MAU & 90 & .69 & 4 & .53 & 18.68 & .53 & 1.75 \\
\hline 44 & Mexico/MEX & 65 & -.27 & 4 & .53 & 14.96 & -.33 & -0.07 \\
\hline 45 & Mozambique/MOZ & 56 & -.62 & 4 & .53 & 10.11 & -1.46 & -1.55 \\
\hline 46 & Namibia/NAM & 77 & .18 & 4 & .53 & 14.50 & -.44 & 0.27 \\
\hline 47 & Netherlands/NTH & 99 & 1.04 & 4 & .53 & 21.11 & 1.09 & 2.66 \\
\hline 48 & New Zealand/NZ & 98 & 1.00 & 4 & .53 & 7.40 & -2.09 & -0.56 \\
\hline 49 & Nigeria/NIG & 48 & -.93 & 4 & .53 & 16.56 & .03 & -0.37 \\
\hline 50 & Panama/PAN & 83 & .42 & 1 & -2.15 & 14.89 & -.35 & -2.08 \\
\hline 51 & Peru /PER & 71 & -.04 & 3 & -.36 & 15.11 & -.30 & -0.70 \\
\hline 52 & Philippines/PHI & 65 & -.27 & 4 & .53 & 15.28 & -.26 & 0 \\
\hline 53 & Poland/POL & 93 & .80 & 4 & .53 & 17.08 & .15 & 1.48 \\
\hline 54 & Portugal/POR & 97 & .96 & 4 & .53 & 13.05 & -.78 & 0.71 \\
\hline 55 & Russia/RUS & 22 & -1.94 & 1 & -2.15 & 12.38 & -.93 & -5.02 \\
\hline 56 & Slovakia/SLK & 89 & .65 & 4 & .53 & 17.34 & .21 & 1.39 \\
\hline 57 & Slovenia/SLV & 92 & .76 & 4 & .53 & 19.03 & .61 & 1.90 \\
\hline 58 & S. Africa/S AF & 79 & .26 & 4 & .53 & 15.19 & -.28 & 0.51 \\
\hline 59 & S. Arabia/S AR & 10 & -2.40 & 4 & .53 & 18.32 & .44 & -1.43 \\
\hline 60 & Singapore/SIN & 51 & -.81 & 4 & .53 & 16.56 & .03 & -0.25 \\
\hline 61 & S. Korea/SKO & 83 & .42 & 4 & .53 & 14.40 & -.46 & 0.49 \\
\hline 62 & Spain/SPA & 95 & .88 & 4 & .53 & 14.73 & -.38 & 1.03 \\
\hline 63 & Sweden/SWE & 100 & 1.07 & 4 & .53 & 24.19 & 1.81 & 3.41 \\
\hline 64 & Switzerland/SWZ & 96 & .92 & 4 & .53 & 17.00 & .13 & 1.58 \\
\hline 65 & Thailand/THA & 32 & -1.55 & 4 & .53 & 17.36 & .22 & -0.80 \\
\hline 66 & Tunisia/TUN & 79 & .26 & 4 & .53 & $8.40 *$ & -1.86 & -1.07 \\
\hline 67 & Turkey/TUR & 53 & -.74 & 4 & .53 & 15.57 & -.19 & -0.40 \\
\hline 68 & $\begin{array}{l}\text { United } \\
\text { Kingdom/UK }\end{array}$ & 95 & .88 & 4 & .53 & 19.00 & .60 & 2.01 \\
\hline 69 & USA/USA & 90 & .69 & 4 & .53 & 14.19 & -.51 & 0.71 \\
\hline \multirow[t]{3}{*}{70} & Uruguay/URU & 98 & 1.00 & 4 & .53 & 14.50 & -.44 & 1.09 \\
\hline & Mean & 71.68 & & 3.38 & & 16.63 & & -0.09 \\
\hline & Std. Deviation & 26.05 & & 1.12 & & 4.16 & & 2.02 \\
\hline
\end{tabular}




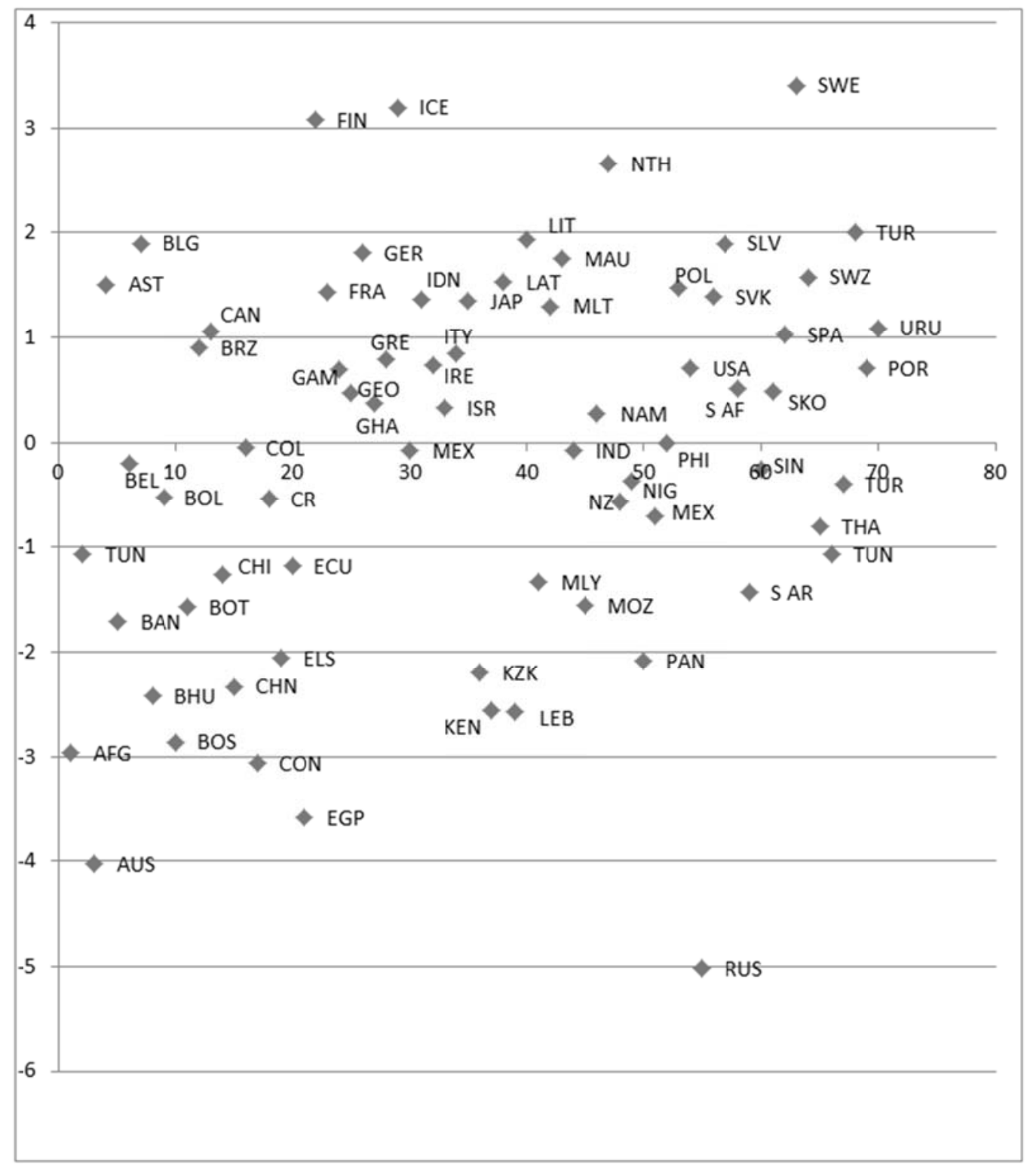

Figure 1. Scores for freedom and bank capacity- 70 nations

\section{Pros, Cons, and Implementation}

For 70 nations, the mean freedom score was $71 / 100$ with a standard deviation of 26 . Regarding banking integrity, (Basel II Implementation) the mean was $3.38 / 4.00$ and for bank system capacity (capital to assets ratio) the mean was 16.63 with no upper theoretical limit on the amount of capital in relation to assets. (The minimum required was 8 percent) The standard deviation was 4.16 . Thirty-five of the 70 nations scored positively when freedom and banking scores were tallied in our typology.

Twenty nations were EU members thus it could be expected that they would have higher scores for banking system capacity and stability. Had consistent data been available, all 194 UN member states would have been included in the typology. For those in favor of a single currency, it may be encouraging to realize that there are 15 non-EU nations (Ghana, Gambia, Namibia, Israel, Indonesia, Japan, Mauritius, Georgia, Brazil, Canada, USA, S. Africa, S. Korea, and Turkey), considered free with capable, stable banking systems that might participate in an initial bloc of adopters. Only the dollar and the euro currently fulfill all 3 roles of money yet from official to anecdotal comment, it seems neither is a 
desired unit. The SDR cannot, at this time, serve as money yet the IMF admits a wish to make that happen. It is true that moving to one single currency would eliminate the exchange rate problem and help reduce balance of payments issues, but all the scores and typologies in the world will not bring it about unless doing so becomes politically acceptable to world leaders.

Oil now trades in different currencies signaling the dollar's decline. The euro is in ascendancy yet the Eurozone quakes under populism and nationalism. Bank stability scores in our typology for EU countries belie the fact that only 5 have maintained their fiscal plans. China's RMB is rising but weak as the needed architecture, will, and skill to manage a global unit are just emerging in China. There is no evident political acceptability for the RMB to go global. Bitcoin is novel, volatile, without central control, poorly understood, without deposit insurance, and susceptible to hacking.

Elevating a single monetary unit to the role of world money would eliminate, eventually, the exchange rate problem and go far in smoothing out imbalances. Business would possess a higher degree of price certainty once the implementation period had concluded. Thousands, if not millions of jobs would be created to study implementation and accommodate the changeover. Global business may explode, soaking up the millions of unemployed. A great levelling of individuals' purchasing power would occur on a global basis if everyone used the same monetary unit. As wars are fought over currency, the entire concept of war financing and operation would take a huge new twist with many new lenders able and willing. Do new lenders become allies? This may change geopolitics.

The SDR would benefit smaller nations that have few dollars held in reserve and may give emerging market economies a leg up. The IMF is a known and customary institution. The architecture and structure are already there even if some members complain about the lack of diversity in management and representation. Those things are remediable.

While geopolitics is not the subject of this paper, it is perhaps an understatement to say that in a one money world, geopolitics would be stood on its head. Chaos might result. Gone would be currency competition that many feel is a good thing. Money is part of a nation's culture and psyche. Would nations continue to find reasons to fight? Some nations may not favor an equalization of purchasing power as they enjoy their imbalance. History is replete with a plethora of attempts to empower less advantaged nations yet hegemony perseveres.

Over 5 trillion dollars are traded each day in the foreign exchange market (forex) [56]. It is difficult to see how the powerful interests who profit from this trade will wither in the face of the one money movement. The forex profit question is not addressed either in institutional papers or scholarly literature and remains the unwashed child of the single currency debate.

However, if the five fiat currencies on which the SDR is based are in some degree of trouble, how is a new fiat unit, created out of the five, any better? What happens to the existing 5 fiat currencies themselves? Do they hang around until the public is comfortable with the new money? No market currently exists for SDRs, they are not freely tradable as a means of exchange, and that coordination of political will to promote the unit as currency does not exist now and does not appear to be on any one's radar, other than the IMF's.

The problems involved in the changeover to the euro would pale in comparison to the problems of moving all 194 UN nations off of their currencies and onto a new unit. Global business, prices for goods and services, every marketing system would have to be rethought. How long would that take and what would happen in the process are two issues that could derail such a large project. Who has the gravitas to parse out rupees, krone, yen, and rubles into a new unit? The IMF and numerous scholars have called for a currency board. Not the slightest bit of conflict there. What would the new unit be called? Care need be taken not to choose a term with socio-cultural baggage: we like "Terra," Latin for land, something everybody has.

In a 1988 editorial in the January issue of The Economist, we are told to get ready for a world currency in thirty years. That time is practically upon us. Assume for a moment that one of the five fiats or the SDR or some derivation thereof, becomes a world currency. How would it be implemented? Many a great-sounding idea has gone down in the flames of poor implementation. Assume a new unit incorporates the best features of all currencies: it is expandable but stable, it is easy to exchange and transmit, and it must represent something of value to all, our "Terra."

Institutions have to cooperate in working out the details. The devil dwells therein. Details are the 800-lb gorilla in the room. The IMF claims there are so many institutions devoted to stabilizing the SDR system that it is unclear which is responsible for what function. The creation of the Financial 
Stability Board (FSB) that rose out of the 2008-2009 crisis is only an advisory body, and the G20 has not been terribly successful at implementing new rules [22]. The new Basel III accord is, as of 2016, as yet not fully implemented and many consider the new regime unsustainable. The United Nations may talk, softly at times, loudly at others, but has no "big stick" with which to enforce any new market mechanism. Nor is there any other national or supranational body with such enforcement power. Sovereign governments refuse to cede economic authority to an international body and finance ministers do not universally well-understand their own systems. So who will run a new currency regime? One supposes the IMF. Furthermore, new, "shadow broker-dealers" have emerged that are entirely unregulated and massive new regulations would be needed to implement a new tradable SDR [22]. Players would have to conform to the rules to make the new SDR market work. Trust, a market, and confidence are simultaneously needed to launch a new supranational currency and those elements are missing from the IMS.

If the IMF suggests that central banks should be the new police that suggestion begs the question of capacity. Given the current situation in which the world finds itself, central banks may be out of tools to right the economic ship and, given that much of the power needed to launch a new single currency is out of their hands, their ability to create one is nonexistent. However, central bank cooperation is essential in every national adopter and the banking system must be robust enough to handle the changeover as it was with the Euro. These are problems of political acceptability. Can leaders and institutions create political consensus? All the scores and typologies in the world cannot create what leaders of the world do not want. If the UN, the G20, the FSB and other think tanks, universities, and government bodies cannot create consensus and force compliance then, short of military force, the IMS is adrift in a sea of disparate domestic monetary imperatives in which nations attempt to serve themselves first. Central banks are also ill-equipped to handle these burdens.

Printing the equivalent amount of new Terra currency would be tantamount to the Treasury Workers Full Employment Act. Which images shall grace the front and back of various denominations? How do we make this new system secure? Electronic architecture has vastly improved anti-theft and anticounterfeiting schemes within the currency itself and inside the engraving and printing bureaus yet all electronic systems remain subject to intrusion. A street-level thought: vending machine changeover and ATMs. But, perhaps an electronic Terra is the way to go. Paper is so yesterday. Electronic banking is, in general, secure and provides a platform from which to manage a currency.

Finally, and perhaps most importantly, what happens to the existing mountains of debt denominated in dollars, euros, yens, and pounds? These important details are noticeably absent from the literature and global debate. One might assume that they would all be converted into Terra, but we know what happens when one assumes. Will the debt be revalued away in a reset? What about future liabilities? Trillions are owed to future publics for social welfare benefits.

When Terra goes live will all other currencies become irrelevant? Do they disappear from use, or would they continue to operate within their relative jurisdictions and fade until the Terra takes over? Psychologically, what does that do to a nation? Money is a primary component of a nation's culture and psyche. If it was not, the Euro would not have posed (and still poses) so much difficulty in its adoption and operation. The question can fairly be asked, how long before countries and businesses simply stop fussing with the exchange of dollars or yen or pounds or euros and simply use Terra? At that point, the Terra becomes money, and the value of the previous fiats fades away. Money is perception.

\section{Conclusion}

A single currency system can be made to work: free countries with stable functioning institutions and solid banking systems exist, but the odds are against it with the present candidates and geopolitical conditions. Not only because proposals are weak compared to the role of money but for geopolitical power, pride, culture, and profit each of which is contextually embedded in the international monetary system. Helleiner said we have no Keynes to show us the way [57]. We know the way but the path is crowded. 


\section{References}

1. M. Carney, "The Evolution of the International Monetary System", Bank of International Settlements, www.bis.org/review/r091123c.pdf, 2009.

2. Bank for International Settlements (BIS, "The International Monetary and Financial System", BIS, Available from: http://www.bis.org/publ/arpdf/ar2015e5.htm, 2015.

3. International Monetary Fund (IMF, "The Role of the SDR", Available: https://www.imf.org/external/np/exr/ facts.sdr.htm, 2015.

4. P. Subacchi, "Who Is in Control of the International Monetary System?", International Affairs, vol. 86, no 3, pp. 665-680, 2010.

5. X. Zhou, "Reform the International Monetary System, Peoples Bank of China". Available: http://www.china.org.cn/business/news/2009-02/24/content_17490662.htm, 2009.

6. P. Alessandrini, and M. Fratianni, "Dominant Currencies, Special Drawing Rights, and Supernational Bank Money", World Economics, vol. 10, no 4, pp. 45-67, 2009.

7. J. Ewing, "E.C.B. Could Be Power Broker in Solving Greek Debt Crisis", New York Times, vol. 19, February, pp. B3, 2015.

8. P. N. Rosenstein-Rodan, "The Coordination of the General Theories of Money and Price", Economica, New Series, vol. 3, no 11, pp.: 257-280, 1936.

9. Freedom House, "Freedom in the World- 2016", Freedom House.org, Available: https://freedomhouse.org/ content/freedom-housesearch?as_q=Freedom\%20in\%20thre\%20World\%202016, 2016.

10.C. F. Kindleberger, "The International Adjustment Mechanism", Federal Reserve Bank of Boston, Conference Series 2. 1969.

11.R. Coats, "Time for a New Global Currency?", New Global Studies, vol. 3, no 1, http://works.bepress.com/ warren_coats/1/, 2010.

12.R. N. Cooper, "A Monetary System for the Future", Foreign Affairs, vol. 63, no 1, pp. 166-184, 1984.

13.F. Hayek, "The De-Nationalization of Money: The Argument Refined". The Nakamoto Institute,

Available: http://nakamotoinstitute.org/static/docs/denationalisation.pdf, 1976.

14.K. Rogoff, "Why Not a Global Currency?" American Economic Review, vol. 91, no 2, pp. 243-47, 2001.

15.R. Mundell, "The Euro, the Dollar and the International Monetary System", Journal of Policy Modeling, vol. 27, no 4, pp. 465-475, 2005.

16.B. Steil, "The End of National Currency", Foreign Affairs, vol. 86, no 3, pp. 83-96, 2007.

17.G. Bird, "Special Drawing Rights: How Fashions Change", World Economics, vol. 11, no 1, pp.83-98. 2010.

18.B. Eichengreen, "When Currencies Collapse: Will We Replay the 1930s or the 1970s?", Foreign Affairs, vol 91, no 1, pp. 117-120, 122-134, 2012.

19.R. Rahn, "A Constant Unit of Account", Cato Journal, vol. 30, no 3, pp. 521-533, 2010.

20._ “One World, One Currency: Destination or Delusion?" IMF Conference Transcript, 8 November, http://www.imf.org/external/np/exr/ecforums/110800.htm, 2000.

21.World Bank. "Global Economic Prospects 2015. Chapter 1, Global Economy in Transition", Available: http://www.worldbank.org/en/publication/global-economic prospects, 2015.

22.Council on Foreign Relations, "The Global Finance Regime", Available: http://www.cfr.org/financial-regulation/ global-finance-regime/p20177, 2013.

23.L. Sarno, and M. Schmeling, "Which Fundamentals Drive Exchange Rates? A Cross-Sectional Perspective", Journal of Money, Credit, and Banking, vol. 46, no 2-3, pp. 267-292, 2014.

24.L. Beckmann, and R. Czudaj, "Exchange Rate Expectations and Economic Policy Uncertainty", European Journal of Political Economy, In Press, 2016.

25.G. Zhang, and R. MacDonald, "Real Exchange Rates, the Trade Balance and Net Foreign Assets: Long-Run Relationships and Measures of Misalignment", Open Economics Review, vol. 25, pp. 635-653, 2014.

26.P. Duarte, and G. Schnabl, "Macroeconomic Policy Making, Exchange Rate Adjustment and Current Account Imbalances in Emerging Markets", Review of Development Economics, vol. 19, no 3, pp.531-544, Available: DOI:10.1111/rode.12168, 2015.

27.T. Straubharr, "Should Central Banks Manage the Exchange Rate?" ZBW-Leibniz Information Centre for Economics, Intereconomics, pp. 161-165. DOI: 10.1007/s10272-015-0537-z, 2015. 
28.N. Herger, "Market Entries and Exits and the Nonlinear Behavior of the Exchange Rate Pass-Through into Import Prices". Open Economic Review, vol. 26, pp.313-332, DOI 10.1007/s11079-014-9331-y, 2015.

29.S. Jahjah, B. Wei, and V. Z. Yue, "Exchange Rate Policy and Sovereign Bond Spreads in Developing Countries", Journal of Money, Credit, and Banking, vol. 45, no 7, pp. 1275-1300, 2013.

30.N. Burckhardt, "Essays on the Correlation of Foreign Exchange Rates", Dissertation 4071, University of St. Gallen, Zurich, 2012.

31.S. Drozdz, A. Gorski, and J. Kwapien, "World Currency Exchange Rate Cross-Correlations", European Physics Journal, vol. B58, pp. 499. (arXiv:0708.4347v1) DOI:10.1140/epjb/e2007-00246-8, 2007.

32.S. Benediktsdóttir, and C. Scotti, "Exchange Rates Dependence: What Drives It?", Federal Reserve Board, International Finance Discussion Paper 969, 2009.

33.R. Moghadam, "Enhancing International Monetary Stability - A Role for the SDR?", International Monetary Fund. Available at: http://www.imf.org/external/np/pp/eng/2010/041310.pdf, 2011.

34.I. Mateos y Lago, R. Duttagupta, and R. Goyal, "The Debate on the International Monetary System", International Monetary Fund, staff position note, Available: http://www.imf.org/external/pubs/ft/spn/2009/ spn0926.pdf, 2009.

35. United Nations, "Press Conference by Department of Economic and Social Affairs to Launch 2009 Asia-Pacific Survey", Available:http://www.un.org/News/briefings/docs/2009/090327_Survey.doc.htm, 2009.

36.P. Volcker, as quoted by Morrison Bonpasse, "The Single Global Currency", (Single Global Currency Association), Available: http://www.singleglobalcurrency.org/, 2006.

37.A. Evans-Pritchard, "A World Currency Moves Nearer after Tim Geithner's Slip", The Telegraph, 26 March. Available: http://www.telegraph.co.uk/finance/economics/5051075/A-world-currency-moves-nearer-after-TimGeithners-slip.html, 2009.

38.CNBC.com. "Pope Calls for New Economic Order: Criticizes Capitalism", CNBC.com, http://www.cnbc.com/ 2015/07/10/, 2015.

39.L. Hatheway, and A. Friedman, "It's Time for Some Sort of Global Money System", Market Watch, 11Nov, Available: http://www.marketwatch.com/story/its-time-for-some-sort-of-global-money-system-2015-11-11? $\bmod =$ googleeconomypolitics, 2015.

40.R. Brenner, "The US Dollar and Prosperity: Accidents Waiting to Happen", Cato Journal, vol. 26, no 2, pp. 317$332,2006$.

41.R. J. Carbaugh, and D. W. Hedrick, "Will the Dollar Be Dethroned as the Main Reserve Currency?", Global Economy Journal, vol. 9, no 3, pp. 1-18. DOI: 10.2202/1524-5861.1541, 2009.

42.A. Higgins, and D. E. Sanger. "3 European Powers Say They Will Join China-Led Bank", New York Times. 17 March, Available: http://www.nytimes.com/2015/03/18/business/france-germany-and-italy - join-asianinfrastructure-investment-bank.html? $\mathrm{r}=0,2015$.

43.J. Rickards, "Currency Wars", New York: Penguin Group, 2011.

44.J. Rickards, "The Death of Money", New York: Penguin Group, 2014.

45.R. Clabough, "Report Says Death of Euro Will Lead to Doomsday", The New American, http://www.thenewamerican.com/world-mainmenu-26/europe-mainmenu-35/8895-report-says-death-of-euro-willlead-to-doomsday, 2011.

46.G. Chavez-Dreyfuss, and A. Nag, "U.S. Dollar Share of FX Reserves Dips in Second Quarter, Euro's at 13-Year Low", Reuters.com, http://www.reuters.com/article/us-currency-reserves-imf-idUSKCN0RU1WM20150930, 2015.

47.The Guardian. "World Shares Soar and Yen Crumbles as QE is Beefed Up in Japan", The Guardian, https://www.theguardian.com/business/2014/nov/02/world-shares-soar-and-yen-crumbles-as-qe-is-beefed-up-injapan, 2014.

48.S. Ammous, "Economics beyond Financial Intermediation: Digital Currencies, Possibilities for Growth, Poverty Alleviation, and International Development", The Journal of Private Enterprise, vol. 30, no 3, pp. 19-50, 2015.

49.M. Malovic, "Demystifying Bitcoin: Sleight of Hand or Major Global Currency Alternative?", Economic Analysis, Institute of Economic Sciences, Belgrade. Project 179015, 2014.

50.M. Van Alstyne, "Why Bitcoin Has Value", Communications of the ACM, vol. 57, no 5, pp. 30-32, 2014.

51.A. R. Sorkin, "Render Unto Caesar, But Who Backs Bitcoin?", The New York Times, 23 November, pp. B1, 2013.

52.International Monetary Fund (IMF),"Virtual currencies and beyond", IMF Staff Discussion Note, 2016. 
53.Thompson-Reuters, "Thompson-Reuters Extends Global Gold Mine Analysis", http://thomsonreuters.com/en/ press-releases/2014/thomson-reuters-extends-global-gold-mine-analysis-in-eikon.html, 2014.

54.World Gold Council, "Latest Gold Reserves", http://www.gold.org/statistics\#group5, 2015.

55.W. Hin, "The Mystery of China's Official Gold Numbers", SeekingAlpha.com, Available: http://seekingalpha.com/article/3323265-the-mystery-of-chinas-official-gold-numbers, 2015.

56. Bank for International Settlements (BIS), "Gross Market Values of OTC Forex Market Exchange", BIS, http://www.bis.org/search/?q=forex+market+value, 2016.

57.E. Helleiner, "Think Globally, Transact Locally: Green Political Economy and the Local Currency Movement", Global Society, vol. 14, no 1, pp. 35-51, 2000. 